Research article

\title{
Buthionine sulfoximine sensitizes antihormone-resistant human breast cancer cells to estrogen-induced apoptosis
}

\author{
Joan S Lewis-Wambi', Helen R Kim¹, Chris Wambi³, Roshani Patel2, Jennifer R Pyle1, \\ Andres J Klein-Szanto ${ }^{4}$ and V Craig Jordan ${ }^{1}$
}

\author{
1Department of Medical Sciences, Fox Chase Cancer Center, 333 Cottman Avenue, Philadelphia, PA, 19111, USA \\ 2Department of Surgical Oncology, Fox Chase Cancer Center, З3з Cottman Avenue, Philadelphia, PA, 19111, USA \\ 3Department of Radiation Oncology, University of Pennsylvania, 195 John Morgan Building, 3620 Hamilton Walk, Philadelphia, PA 19104, USA \\ ${ }^{4}$ Department of Pathology, Fox Chase Cancer Center, 333 Cottman Avenue, Philadelphia, PA, 19111, USA
}

Corresponding author: V Craig Jordan, v.craig.jordan@fccc.edu

Received: 4 Sep 2008 Revisions requested: 22 Oct 2008 Revisions received: 11 Nov 2008 Accepted: 5 Dec 2008 Published: 5 Dec 2008

Breast Cancer Research 2008, 10:R104 (doi:10.1186/bcr2208)

This article is online at: http://breast-cancer-research.com/content/10/6/R104

(C) 2008 Lewis-Wambi et al.; licensee BioMed Central Ltd.

This is an open access article distributed under the terms of the Creative Commons Attribution License (http://creativecommons.org/licenses/by/2.0), which permits unrestricted use, distribution, and reproduction in any medium, provided the original work is properly cited.

\begin{abstract}
Introduction Estrogen deprivation using aromatase inhibitors is one of the standard treatments for postmenopausal women with estrogen receptor (ER)-positive breast cancer. However, one of the consequences of prolonged estrogen suppression is acquired drug resistance. Our group is interested in studying antihormone resistance and has previously reported the development of an estrogen deprived human breast cancer cell line, MCF-7:5C, which undergoes apoptosis in the presence of estradiol. In contrast, another estrogen deprived cell line, MCF7:2A, appears to have elevated levels of glutathione (GSH) and is resistant to estradiol-induced apoptosis. In the present study, we evaluated whether buthionine sulfoximine (BSO), a potent inhibitor of glutathione (GSH) synthesis, is capable of sensitizing antihormone resistant MCF-7:2A cells to estradiolinduced apoptosis.
\end{abstract}

Methods Estrogen deprived MCF-7:2A cells were treated with $1 \mathrm{nM} 17 \beta$-estradiol $\left(\mathrm{E}_{2}\right), 100 \mu \mathrm{M}$ BSO, or $1 \mathrm{nM} \mathrm{E} \mathrm{E}_{2}+100 \mu \mathrm{M}$ $\mathrm{BSO}$ combination in vitro, and the effects of these agents on cell growth and apoptosis were evaluated by DNA quantitation assay and annexin $\mathrm{V}$ and terminal deoxynucleotidyl transferase dUTP nick end-labeling (TUNEL) staining. The in vitro results of the MCF-7:2A cell line were further confirmed in vivo in a mouse xenograft model.
Results Exposure of MCF-7:2A cells to $1 \mathrm{nM} \mathrm{E}_{2}$ plus $100 \mu \mathrm{M}$ BSO combination for 48 to $96 \mathrm{~h}$ produced a sevenfold increase in apoptosis whereas the individual treatments had no significant effect on growth. Induction of apoptosis by the combination treatment of $E_{2}$ plus $B S O$ was evidenced by changes in $\mathrm{Bcl}-2$ and $\mathrm{Bax}$ expression. The combination treatment also markedly increased phosphorylated c-Jun $\mathrm{N}$ terminal kinase (JNK) levels in MCF-7:2A cells and blockade of the JNK pathway attenuated the apoptotic effect of $E_{2}$ plus BSO. Our in vitro findings corroborated in vivo data from a mouse xenograft model in which daily administration of BSO either as a single agent or in combination with $\mathrm{E}_{2}$ significantly reduced tumor growth of MCF-7:2A cells.

Conclusions Our data indicates that GSH participates in retarding apoptosis in antihormone-resistant human breast cancer cells and that depletion of this molecule by BSO may be critical in predisposing resistant cells to $E_{2}$-induced apoptotic cell death. We suggest that these data may form the basis of improving therapeutic strategies for the treatment of antihormone resistant ER-positive breast cancer.

\section{Introduction}

Currently, estrogen deprivation using aromatase inhibitors is one of the standard treatments for postmenopausal women with estrogen receptor (ER)-positive breast cancer [1]. Unfor- tunately, a major clinical problem with the use of prolonged estrogen deprivation is the development of drug resistance (that is, hormone-independent growth) [2,3]. Our laboratory as well as other investigators, have instigated a major effort in

BSO: L-buthionine sulfoximine; $\mathrm{E}_{2}$ : 17 $\beta$-estradiol; ER: estrogen receptor; FBS: fetal bovine serum; GCS: glutamylcysteine; GPx2: glutathione peroxidase; GS: glutathione synthetase; GSH: glutathione; H\&E: hematoxylin and eosin; JNK: c-Jun N-terminal kinase; Rh123: rhodamine 123; SFS: dextran coated charcoal-treated FBS; TUNEL: terminal deoxynucleotidyl transferase-mediated dUTP nick end-labeling. 
studying antihormone resistance in breast cancer and have developed model systems of estrogen deprivation that are sensitive [4-6] or resistant to the apoptotic actions of estrogen [7]. In particular, we have previously reported the development of an estrogen deprived breast cancer cell line, MCF-7:5C, which undergoes estradiol-induced apoptosis after 2 days of treatment via the mitochondrial pathway [8]. In contrast, we have another estrogen deprived breast cancer cell line, MCF$7: 2 \mathrm{~A}$, which appears to be resistant to estradiol-induced apoptosis [7]. We are studying resistance to estrogen induced apoptosis because clinical experience shows us that only $30 \%$ of patients respond to estrogen induced apoptosis once exhaustive antihormonal therapy occurs [9]. An important goal would be to see whether the apoptotic effect of estrogen can be enhanced in antihormone resistant cells. This new, targeted approach to the treatment of metastatic breast cancer could open the door to novel approaches to treatment with drug combinations.

L-Buthionine sulfoximine (BSO) is a specific $\gamma$-glutamylcysteine synthetase inhibitor that blocks the rate-limiting step of glutathionine (GSH) biosynthesis and in doing so depletes the intracellular GSH pool in both cultured cells and in whole animals [10]. GSH is a water-soluble tripeptide composed of glutamine, cysteine, and glycine. Reduced glutathione is the most abundant intracellular small molecule thiol present in mammalian cells and it serves as a potent intracellular antioxidant protecting cells from toxins such free radicals $[11,12]$. Changes in GSH homeostasis have been implicated in the etiology and progression of a variety of human diseases, including breast cancer [13]. In particular, studies have shown that elevated levels of GSH prevent apoptotic cell death whereas depletion of GSH facilitates apoptosis [10,14]. BSO depletes cellular GSH [10] and sensitizes tumor cells to apoptosis induced by standard chemotherapeutic agents $[15,16]$.

Apoptosis (programmed cell death) is required for normal development and tissue homeostasis in multicellular organisms. Deregulation of apoptosis is fundamental to many diseases, such as cancer, stroke, heart disease, neurodegenerative disorders, and autoimmune disorders [17]. There are two main pathways for apoptosis, namely the extrinsic receptor mediated pathway and the intrinsic mitochondriamediated pathway $[18,19]$. Components of the extrinsic pathway include the death receptors FasR/FasL, DR4/DR5, and tumor necrosis factor (TNF) [20], whereas the intrinsic pathway centers on the $\mathrm{Bcl}-2$ family of proteins which comprises both proapoptotic proteins, such as Bax, Bak, and Bid and antiapoptotic proteins, such as Bcl-2 and Bcl-xL $[18,19]$. The $\mathrm{Bcl}-2$ family proteins regulate apoptosis by altering mitochondrial membrane permeabilization which leads to the release of apoptogenic factors such as cytochrome $c$, procaspases, and apoptosis inducing factor (AIF). In particular, Bcl-2 and Bcl-xL inhibit apoptosis by maintaining mitochondrial membrane integrity whereas Bax and Bak facilitate apoptosis by initiating the loss of outer mitochondrial integrity [21]. Apart from its action on the mitochondria, there is also evidence that $\mathrm{Bcl}-2$ possesses antioxidant property. $\mathrm{Bcl}-2$ overexpression increases cellular GSH level which is associated with increased resistance to chemotherapy-induced apoptosis $[22,23]$ whereas $\mathrm{GSH}$ depletion restores apoptosis in Bcl-2 expressing cells [16].

Based on microarray studies we found that the antihormone resistant MCF-7:2A cells express markedly elevated levels of glutathione synthetase (GS) and glutathione peroxidase 2 (GPx2); two enzymes that are involved in glutathione synthesis, which suggests that resistance to estrogen-induced apoptosis might be due to elevated levels of GSH present in the cells. If MCF-7:2A cells do indeed possess high levels of $\mathrm{GSH}$, then it is possible that the use of BSO - as a single agent - might be able to sensitize these cells to estrogeninduced apoptosis. As mentioned before, there is current clinical interest in using low dose estradiol therapy to treat antihormone resistant breast cancer [24] however only a minimal $30 \%$ of patients respond to this therapeutic strategy. A combination of BSO and estradiol could possibly be used to improve the efficacy of estradiol as an apoptotic agent if glutathione depletion is fundamental to tumor cell survival. We have addressed the hypothesis that by altering glutathione levels we may be able to enhance apoptosis to estrogen and have employed BSO as our agent of choice because of earlier work clinically, which may provide a foundation for subsequent clinical trials.

In the present study, we show that depletion of cellular GSH by BSO sensitizes antihormone-resistant MCF-7:2A cells to estradiol-induced apoptosis that is mediated, in part, by the mitochondrial pathway and also activation of the c-Jun $\mathrm{N}$-terminal kinase (JNK) signaling pathway. We further show that $\mathrm{BSO}$, either alone or in combination with estradiol, causes tumor regression of MCF-7:2A cells in vivo.

\section{Materials and methods Cell lines and reagents}

The MCF-7 human breast cancer cell line was obtained from Dr Dean Edwards (University of Texas, San Antonio, TX, USA) and was maintained in phenol red RPMl 1640 medium supplemented with $10 \%$ fetal bovine serum (FBS), $2 \mathrm{mM}$ glutamine, $100 \mathrm{U} / \mathrm{mL}$ penicillin, $100 \mu \mathrm{g} / \mathrm{mL}$ streptomycin, $1 \times$ non-essential amino acids and bovine insulin at $6 \mathrm{ng} / \mathrm{mL}$. The clonal cell line, MCF-7:2A, was derived by growing MCF-7 cells in estrogen-free media for more than 1 year, followed by two rounds of limiting dilution cloning [7]. These cells were grown in phenol red-free RPMl 1640 medium supplemented with $10 \% 4 \times$ dextran-coated, charcoal-treated FBS (SFS). All reagents for cell culture were obtained from Invitrogen (Life Technologies, Carlsbad, CA, USA). DL-Buthionine sulfoximine (BSO) and $17 \beta$-estradiol $\left(E_{2}\right)$ were from Sigma (St Louis, MO, USA), rhodamine 123 (Rh123) was from Invitrogen (Life Technoli- 
gies, Carlsbad, CA, USA). LY294002 and SP600125 were from EMD (Gibbstown, NJ, USA)

\section{Western blot analysis}

The antibodies used for western blotting included those against stress-activated protein kinase (SAPK)/JNK, phosphoSAPK/JNK (Thr183/Tyr185), caspase-7, caspase-9, phospho-Bcl-2 (Ser70), and poly(ADP-ribose) polymerase (PARP) (Cell Signaling Technology, Danvers, MA, USA), cytochrome $c$ and $\beta$-actin (Sigma, St Louis, MO, USA), cytochrome oxidase subunit IV (Cox IV; Invitrogen, Carlsbad, CA, USA), Bax, Bcl-2, and Bcl-xL (Santa Cruz Biotechnology, Santa Cruz, CA, USA). Western blotting analysis was performed as previously described [8].

\section{Cell proliferation assays}

Proliferation assay was performed as previously described [8]. Briefly, MCF-7 and MCF-7:2A cells were seeded in estrogenfree RPMI media containing $10 \%$ SFS at a density of $2 \times 10^{4}$ cells per well in 24-well plates. After $24 \mathrm{~h}$, cells were treated with the respective drugs for 2,5 , and 7 days with retreatment on alternate days. The DNA content of the cells was determined as previously described [25] using a Fluorescent DNA Quantitation kit (Bio-Rad, Hercules, CA, USA). For each analysis, six replicate wells were used, and at least three independent experiments were performed.

Cell proliferation was also determined by cell counting using a hemocytometer. MCF-7 and MCF-7:2A cells were seeded at a density of $0.5 \times 10^{6}$ cells in $100 \mathrm{~mm}$ dishes and after $24 \mathrm{~h}$ cells were treated with $1 \mathrm{nME}_{2}, 100 \mu \mathrm{MBSO}$, or $1 \mathrm{nM} \mathrm{E}_{2}$ plus $100 \mu \mathrm{M}$ BSO for 7 days with re-treatment on alternate days. For each analysis, three replicate dishes were used, and at least three independent experiments were performed.

\section{Detection of apoptosis by annexin $\mathbf{V}$ staining}

The annexin V-fluorescein isothiocyanate (FITC) labeled Apoptosis Detection Kit I (BD Biosciences, San Jose, CA, USA) was used to detect and quantify apoptosis by flow cytometry, according to the manufacturer's instructions.

\section{Terminal deoxynucleotidyl transferase-mediated dUTP nick end-labeling (TUNEL) staining for apoptosis}

Apoptosis was also determined by the TUNEL assay using an in situ cell death detection kit conjugated with horse-radish peroxidase (POD) (Roche Applied Science, Indianapolis, IN, USA), according to the manufacturer's instructions. Briefly, fixed cells were washed, permeabilized, and then incubated with $50 \mu \mathrm{L}$ of terminal deoxynucleotidyl transferase end-labeling cocktail for $60 \mathrm{~min}$ at $37^{\circ} \mathrm{C}$ in a humidified atmosphere in the dark. For signal conversion, slides were incubated with 50 $\mu \mathrm{L}$ of converter-POD (anti-fluorescein antibody conjugated with horseradish peroxidase) for $30 \mathrm{~min}$ at $37^{\circ} \mathrm{C}$, rinsed with PBS, and then incubated with $50 \mu \mathrm{L}$ of 3,3'-diaminobenzidine (DAB) substrate solution for $10 \mathrm{~min}$ at $25^{\circ} \mathrm{C}$. The slides were then rinsed with phosphate-buffered saline (PBS), mounted under glass coverslips, and analyzed under a light microscope using an inverted Nikon TE300 (Nikon, Melville, NY, USA).

\section{GSH assay}

Total cellular GSH was measured using the Total Glutathione Colorimetric microplate assay Kit (Oxford Biomedical Research), according to the manufacturer's protocol. Cells were plated at $0.5 \times 10^{6} /$ well of a six-well plate and allowed to recover overnight. After appropriate treatments, cells were washed in PBS and then lysed in 100 to $150 \mu \mathrm{l}$ of buffer (100 $\mathrm{mM} \mathrm{NaPO}, 1 \mathrm{mM}$ ethylenediaminetetraacetic acid (EDTA), $\mathrm{pH} 7.5$ ) containing $0.1 \%$ Triton $\mathrm{X}-100$ and frozen at $-80^{\circ} \mathrm{C}$ until analysis. To measure total glutathione, proteins were precipitated with sulfosalicylic acid at a final concentration of $1 \%$. Samples were then spun for $10 \mathrm{~min}$ in a microcentrifuge to pellet proteins, and supernatant was diluted 1:20 in buffer before being measured. For all measurements, 50- $\mu$ l triplicates of each sample were used for glutathione determination. The GSH level was obtained by comparing with the GSH standards and represented as $\mathrm{nmol} / \mathrm{mg}$ of protein.

\section{Mitochondrial transmembrane potential $\left(\Delta \Psi_{m}\right)$ and cytochrome c release}

Changes in the mitochondrial membrane potential $(\Delta \Psi \mathrm{m})$ were examined by monitoring the cells after staining with rhodamine 123. Briefly, estradiol plus BSO-treated MCF-7:2A cells were washed twice with PBS and incubated with $1 \mu \mathrm{g} /$ $\mathrm{mL}$ rhodamine 123 at $37^{\circ} \mathrm{C}$ for $30 \mathrm{~min}$. Cells were then washed twice with PBS, and Rh123 intensity was determined by flow cytometry. Cells with reduced fluorescence were counted as having lost some of their mitochondrial membrane potential.

For cytochrome $c$ release assays, cells were lysed in lysis buffer (10 mmol/L N-2-hydroxyethylpiperazine- $N$ '-2-ethanesulfonic acid (HEPES; pH 7.5), $10 \mathrm{mmol} / \mathrm{L} \mathrm{KCl}$, and $1 \mathrm{mmol} / \mathrm{L}$ EDTA) with protease inhibitor cocktail (Sigma), frozen and thawed three times, and centrifuged at 2,000 $\mathrm{g}$ for $5 \mathrm{~min}$. The supernatants were centrifuged at $10,000 \mathrm{~g}$ for $15 \mathrm{~min}$ at $4^{\circ} \mathrm{C}$, and the mitochondrial pellets were dissolved in sodium dodecyl sulfate (SDS) sample buffer, subjected to $15 \%$ SDSpolyacrylamide gel electrophoresis (SDS-PAGE), and analyzed by immunoblotting with monoclonal antibodies against cytochrome $c$ and Cox IV.

\section{RNA isolation and quantitative real-time polymerase chain reaction (PCR)}

Total RNA was isolated using TRI reagent (Invitrogen) according to the manufacturer's protocol. RNA $(2 \mu \mathrm{g})$ was reverse transcribed to cDNA using the SuperScript II RNase Hreverse transcriptase system (Invitrogen, Carlsbad, CA, USA). Aliquots of the CDNA were combined with the SYBR green kit and primers, and assayed in triplicate by real-time quantitative PCR using a GeneAmp ${ }^{\circledR} 5700$ Sequence detection system 
(Applied Biosystems Inc, Foster City, CA, USA). Quantitation was performed using the comparative threshold cycle $(\mathrm{Ct})$ method with 18S rRNA as the normalization gene, as previously described [8]. GS and GPx2 primers were designed using Primer Express ${ }^{\mathrm{TM}}$ software following the manufacturer's guidelines. Primers were synthesized by Applied Biosystems. Quantitative PCR was performed using the following conditions: 40 cycles; denaturation at $95 \mathrm{C}$ for $15 \mathrm{~s}$, annealing at 63 $\mathrm{C}$ for $1 \mathrm{~min}$, and polymerization at $72 \mathrm{C}$ for $1 \mathrm{~min}$. Primer sequences were: GS forward: CACCAGCT GGGGAAGCATCT; reverse: GGTGAGGGGAAGAGCGT GAA, GPx2 forward: TTG ATT AAG GCT TTC TTT GGT AGG; reverse: TTT CAA TAA ATC AGG TCC CAG G.

\section{Small interfering RNA (siRNA) transfection}

Bcl-2-specific siRNA was chemically synthesized by Dharmacon Inc (Chicago, IL, USA). A non-targeting siRNA duplex was used as negative control. For transfection, MCF-7:2A cells were seeded in complete medium without antibiotics the day before the experiment in 12-well plates at a density of 70,000 cells per well. After $24 \mathrm{~h}$, cells were transfected with $100 \mathrm{nM}$ of Bcl-2 siRNA or control siRNA, using DharmaFect 1 transfection reagent (Dharmacon Inc, Chicago, IL, USA), according to the manufacturer's protocol. The cells were harvested $48 \mathrm{~h}$ post transfection and analyzed by western blot. Transfected cells were also treated with estradiol for an additional $72 \mathrm{~h}$ and apoptotic cells were measured using annexin $\mathrm{V}$ staining.

\section{Inhibition of MCF-7:2A cell tumorigenesis by BSO in nude mice}

Female CrTac:NCr-Foxn 1 nu athymic mice (4 to 5 weeks old) were purchased from Taconic (Germantown, NY, USA). Animal experiments were conducted at the Fox Chase Cancer Center (Philadelphia, PA, USA). The research protocol was approved, and mice were maintained in accordance with institutional guidelines of the Fox Chase Cancer Center Animal Care and Use Committee. Mice were acclimatized to the animal facility for 1 week before they received injections of MCF7:2A human breast cancer cells: $2 \times 10^{7}$ cells were resuspended in $100 \mu \mathrm{L}$ PBS (Collaborative Biomedical Products, Bedford, MA, USA) and were bilaterally injected into the mammary fat pads of 20 ovariectomized mice. Tumors were allowed to develop for 20 days until they reached a mean cross-sectional area of $0.32 \mathrm{~cm}^{2}$, when treatment was initiated with placebo (saline), $E_{2}(0.3 \mathrm{~cm}$ capsule), BSO $(4 \mathrm{mmol} / \mathrm{kg}$ weight), or BSO (4 mmol/kg weight) plus $E_{2}(0.3 \mathrm{~cm}$ capsule) for an additional 7 days. For the estradiol treatment, $0.3 \mathrm{~cm}$ silastic estradiol capsules (Baxter HealthCare, Mundeleine, IL, USA) were implanted subcutaneously in the mice. These capsules produced a mean serum estradiol level of $83.8 \mathrm{pg} / \mathrm{mL}$ [26], to achieve postmenopausal serum levels of estradiol. BSO was dissolved in saline and was administered intraperitoneally daily for 7 days. The cross-sectional tumor area was calculated by multiplying the length (I) by the width $(w)$ by $\pi$ and dividing the product by $4(/ w \pi / 4)$. Animals were given food and water ad libitum. Mice from each group $(n=5)$ were killed at the conclusion of the experiment and immunohistochemical analysis was performed.

\section{Tissue preparation and immunohistochemistry}

Tumors from mice treated with placebo, $\mathrm{E}_{2}, \mathrm{BSO}$, or $\mathrm{BSO}$ plus $E_{2}$ were excised and fixed in $10 \%$ formalin, embedded in paraffin wax blocks and sectioned. Subsequently, sections of the tumor blocks were stained with hematoxylin and eosin (H\&E), Ki67, or PARP antibody (1:500 dilution, Santa Cruz Biotechnology, Santa Cruz, CA, USA) by the pathology core facility at Fox Chase Cancer Center.

\section{Statistical analysis}

Statistical analysis was performed using the Student $t$ test, and a $p$ value of $<0.05$ was considered significant. Data are expressed as the mean \pm standard error of the mean (SEM). The mean value was obtained from at least three independent experiments.

\section{Results \\ Estrogen deprivation increases glutathione levels in MCF-7:2A breast cancer cells}

Elevated glutathione levels and the activity of its related enzymes have been characterized as one of the factors which could render breast cancer cells resistant to apoptosis. We have previously shown that MCF-7:2A breast cancer cells are resistant to estrogen-induced apoptosis [7], therefore we measured glutathione levels in these cells along with parental MCF-7 cells. Figure 1a showed that glutathione levels were significantly higher in MCF-7:2A cells (11.9 $\mu \mathrm{M} / \mathrm{mg}$ protein) compared to MCF-7 cells ( $7.8 \mu \mathrm{M} / \mathrm{mg}$ protein) and treatment with BSO $(100 \mu \mathrm{M})$, an inhibitor of glutathione synthesis, for $24 \mathrm{~h}$ depleted glutathione content by approximately $55 \%$ and $68 \%$ in MCF-7 and MCF-7:2A cells, respectively. It is worth noting that glutathione levels were consistently elevated in MCF-7:2A cells up to 7 days and the inhibitory effect of BSO persisted throughout that incubation period (Figure 1a, insert).

We next examined whether the expression of glutathionerelated enzymes was altered in these cells. Using quantitative real-time PCR, we found a 6-fold increase in glutathione synthetase (GS) expression and a 40-fold increase in glutathione peroxidase 2 (GPx2) expressions in MCF-7:2A cells compared to parental MCF-7 cells (Figure 1b). Western blot analysis also showed a marked increase in GS protein level in MCF-7:2A cells compared to parental MCF-7 cells (Figure 1b, right panel).

\section{BSO enhances the apoptotic effect of $E_{2}$ in MCF-7:2A cells}

We next examined whether depletion of glutathione levels by BSO sensitizes MCF-7:2A cells to estrogen-induced apoptosis. For proliferation assays, MCF-7 and MCF-7:2A cells were 
(a)

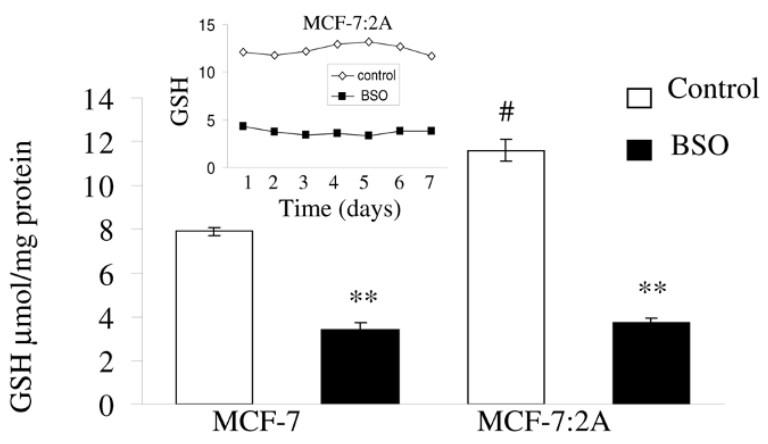

(b)
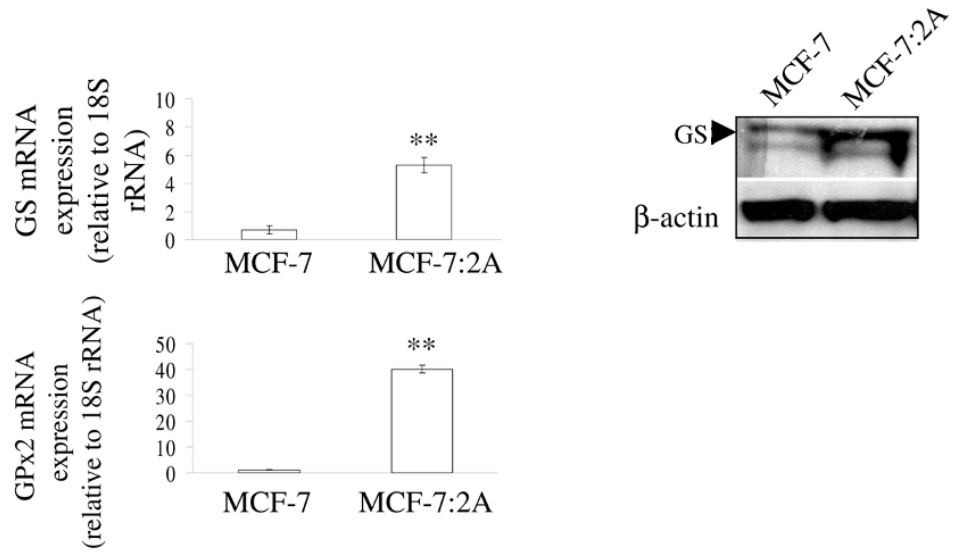

Intracellular glutathione (GSH) levels in wild-type MCF-7 cells and antihormone-resistant MCF-7:2A breast cancer cells. (a) MCF-7 and MCF-7:2A cells were seeded at $2 \times 10^{6}$ cells per $100 \mathrm{~mm}$ culture plates in phenol red RPMI media containing $10 \%$ fetal bovine serum (FBS) and phenol redfree RPMI media containing 10\% 4× dextran coated charcoal-treated FBS (SFS), respectively, and after $24 \mathrm{~h}$ were treated with nothing (control) (white columns) or $100 \mu \mathrm{M}$ buthionine sulfoximine (BSO) (black columns) for $24 \mathrm{~h}$. Total cellular glutathione was measured using a Glutathione Colorimetric microplate assay kit, as described in Materials and methods. Columns, mean from three separate experiments; bars, \pm standard error of the mean (SEM). ${ }^{*}, p<0.001$ compared with control cells; ${ }^{*}, p<0.05$ compared with MCF-7 control cells. Insert graph shows glutathione levels in MCF-7:2A cells over a 7-day period. (b) Quantitative real-time polymerase chain reaction (PCR) of glutathione sythetase (GS) (top left) and glutathione peroxidase 2 (GPx2) (bottom left) mRNA expression in MCF-7 and MCF-7:2A cells. ${ }^{* *}, p<0.001$ compared with MCF-7 control cells. Western blot analysis of GS protein expression in MCF-7:2A cells is also shown (top right).

seeded in estrogen-free media, and after $24 \mathrm{~h}$, were treated with $100 \mu \mathrm{M} \mathrm{BSO}, 1 \mathrm{nM} \mathrm{E}_{2}$, or $100 \mu \mathrm{M}$ BSO plus $1 \mathrm{nM}$ estradiol for 2, 5, and 7 days. Figure 2a shows that the growth of parental MCF-7 cells was stimulated sevenfold over the control cells by $1 \mathrm{nM}$ estradiol during the course of the 7-day assay and that treatment with BSO, either alone or in combination with estradiol, did not significantly alter the growth of these cells. In contrast, MCF-7:2A cells treated with the combination of $100 \mu \mathrm{M}$ BSO and $1 \mathrm{nM}$ estradiol showed a significant time-dependent decrease in cell growth relative to cells treated with either estradiol or BSO alone. The growth inhibitory effect of BSO and estradiol was observed as early as 48 $\mathrm{h}$ after treatment and persisted over the time course of the experiment with maximum cell death at the 7-day time point. The combination of estradiol plus BSO also significantly reduced the proliferation of MCF-7:2A cells (Fig. 2c, bottom) but it did not affect the growth of wild type MCF-7 cells (Figure 2c, top). Furthermore, we found that treatment with the antiestrogen 4-hydroxytamoxifen (4-OHT) almost completely reversed the growth inhibitory effect of estradiol and BSO in MCF-7:2A cells (see Additional data file 1 ) which suggests the involvement of the ER in this process.

Based on the above finding, we next determined whether MCF-7:2A cells underwent apoptotic cell death upon BSO and estradiol treatment. We performed a TUNEL assay, which detects the fragmentation of DNA, which is characteristic of cells undergoing apoptotic cell death. As shown in Figure 3a, the percentage of TUNEL-positive cells significantly increased with the combination of BSO and estradiol but not with estradiol or BSO alone. After treatment with BSO and estradiol (96 h), as many as $53 \%$ of cells displayed TUNEL-positive staining, whereas, only $1 \%$ of the control cells and $5 \%$ of the estradiol-treated cells were TUNEL-positive. BSO-treated cells 
(a)

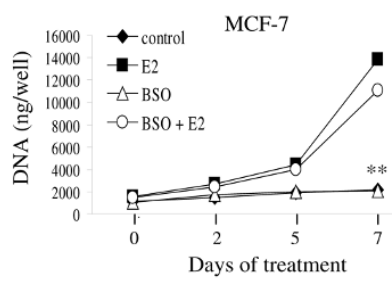

(b)

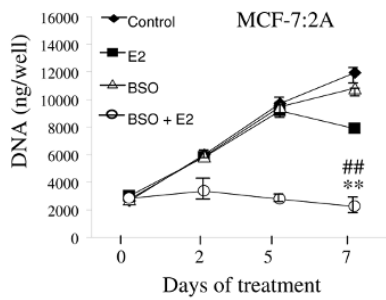

(c)

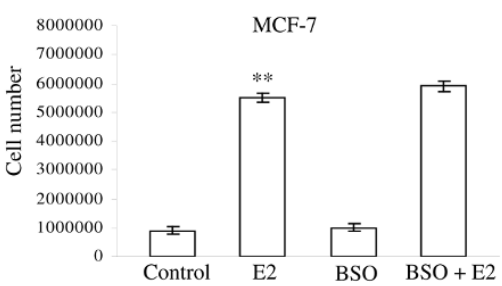

8000000

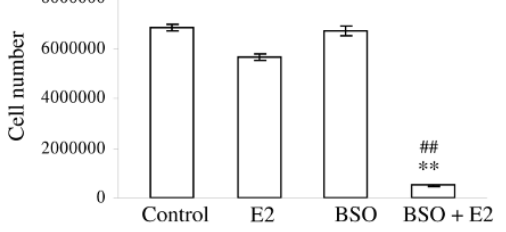

Effect of buthionine sulfoximine (BSO) plus estradiol on the growth of wild-type MCF-7 cells and antihormone-resistant MCF-7:2A cells. (a) MCF-7 cells were grown in estrogen-free media for 3 days prior to the start of the growth assay. On the day of the experiment, 30,000 cells were seeded in 24-well plates and after $24 \mathrm{~h}$ were treated with $<0.1 \%$ ethanol vehicle (control), $1 \mathrm{nM} 17 \beta$-estradiol $\left(\mathrm{E}_{2}\right), 100 \mu \mathrm{M} \mathrm{BSO}$, or $100 \mu \mathrm{M}$ BSO plus $1 \mathrm{nM}$ $\mathrm{E}_{2}$ for 7 days. At the indicated time points, cells were harvested and total DNA (ng/well) was quantitated as described in Materials and methods. The data represent the mean of three independent experiments; bars, \pm standard error of the mean (SEM). ${ }^{* *}, p<0.001$ compared with control cells. (b) MCF-7:2A cells were seeded at the same density as MCF-7 cells and were treated similarly. The data represent the mean of three independent experiments; bars, \pm SEM. ${ }^{* *}, \mathrm{p}<0.001$ compared with control cells; \#\#, $\mathrm{p}<0.001$ compared with estradiol-treated cells. (c) The effect of BSO plus estradiol on cell proliferation was also determined by cell counting using a hemocytometer. For experiment, $0.5 \times 10^{6} \mathrm{MCF}-7$ (top) and MCF$7: 2 \mathrm{~A}$ (bottom) cells were seeded in $15-\mathrm{cm}$ dishes and after $24 \mathrm{~h}$ were treated with $1 \mathrm{nM}$ estradiol, $100 \mu \mathrm{M} \mathrm{BSO}$, or $\mathrm{E}_{2}$ plus BSO combination for 7 days. Data shown represents the mean of three independent experiments; bars, \pm SEM. ${ }^{\star \star}, p<0.001$ compared with control cells; $\# \#, p<0.001$ compared with estradiol-treated cells.

looked similar to control cells. As expected, parental MCF-7 cells showed very little TUNEL-positive staining in the presence of estradiol alone or BSO plus estradiol combined (Figure $2 \mathrm{~b}$, top panel), thus indicating a lack of apoptosis in these cells.

To further substantiate the apoptotic effect of BSO and estradiol in MCF-7:2A cells, annexin V-PI immunostaining was performed by flow cytometry. Figure $3 b$ shows that in the BSO plus estradiol-treated group, approximately $55.6 \%$ of cells stained positive for annexin $\mathrm{V}$ whereas in the control group and estradiol-treated group, approximately $7.4 \%$ and approximately $15.6 \%$, respectively, of cells stained positive for annexin V. For the BSO-treated group, only $8.7 \%$ of cells stained positive for annexin.

\section{Role of the mitochondrial pathway in BSO plus estradiol- induced apoptosis in MCF-7:2A cells}

To examine the role of the mitochondrial pathway in BSO plus estradiol-induced apoptosis, western blot analyses was used to measure $\mathrm{Bax}, \mathrm{Bcl}-2$, phosphorylated $\mathrm{Bcl}-2$, and $\mathrm{Bcl}-\mathrm{xL}$ protein levels in MCF-7:2A cells following treatment with $1 \mathrm{nM}$ estradiol alone, $100 \mu \mathrm{M}$ BSO, or BSO plus estradiol for $48 \mathrm{~h}$. We found that $\mathrm{Bcl}-2$, phospho-Bcl-2, and Bcl-xL protein levels were almost completely reduced in MCF-7:2A cells treated with BSO plus estradiol compared to control, BSO, or estradiol alone. In addition, a marked increase in Bax expression was also observed in MCF-7:2A cells following BSO plus estradiol combined treatment (Figure 4a). In contrast, similar experiments performed with parental MCF-7 cells showed that BSO plus estradiol slightly increased $\mathrm{Bcl}-2$ and phospho-Bcl2 protein levels in these cells with a more dramatic effect observed with estradiol alone (Figure 4a). It is worth noting that in MCF-7:2A cells endogenous levels of Bcl-2 and phosphorylated $\mathrm{Bcl}-2$ were markedly elevated compared to parental MCF-7 cells. This finding is consistent with previous reports which show that overexpression of $\mathrm{Bcl}-2$ increases glutathione levels and inhibits mitochondrial dysfunction and cell death elicited by glutathione-depleting reagents [27].

Although estradiol, as an individual treatment, did not significantly induce apoptosis in MCF-7:2A cells, it did decrease $\mathrm{Bcl}-2$ protein level in these cells. We therefore tested whether siRNA knockdown of $\mathrm{Bcl}-2$ expression would sensitize MCF7:2A cells to estradiol-induced apoptosis. Expression of $\mathrm{Bcl}-2$ following knockdown was analyzed by western blotting. As expected, Bcl-2 protein levels were significantly reduced following transfection of MCF-7:2A cells with Bcl-2 siRNA com- 


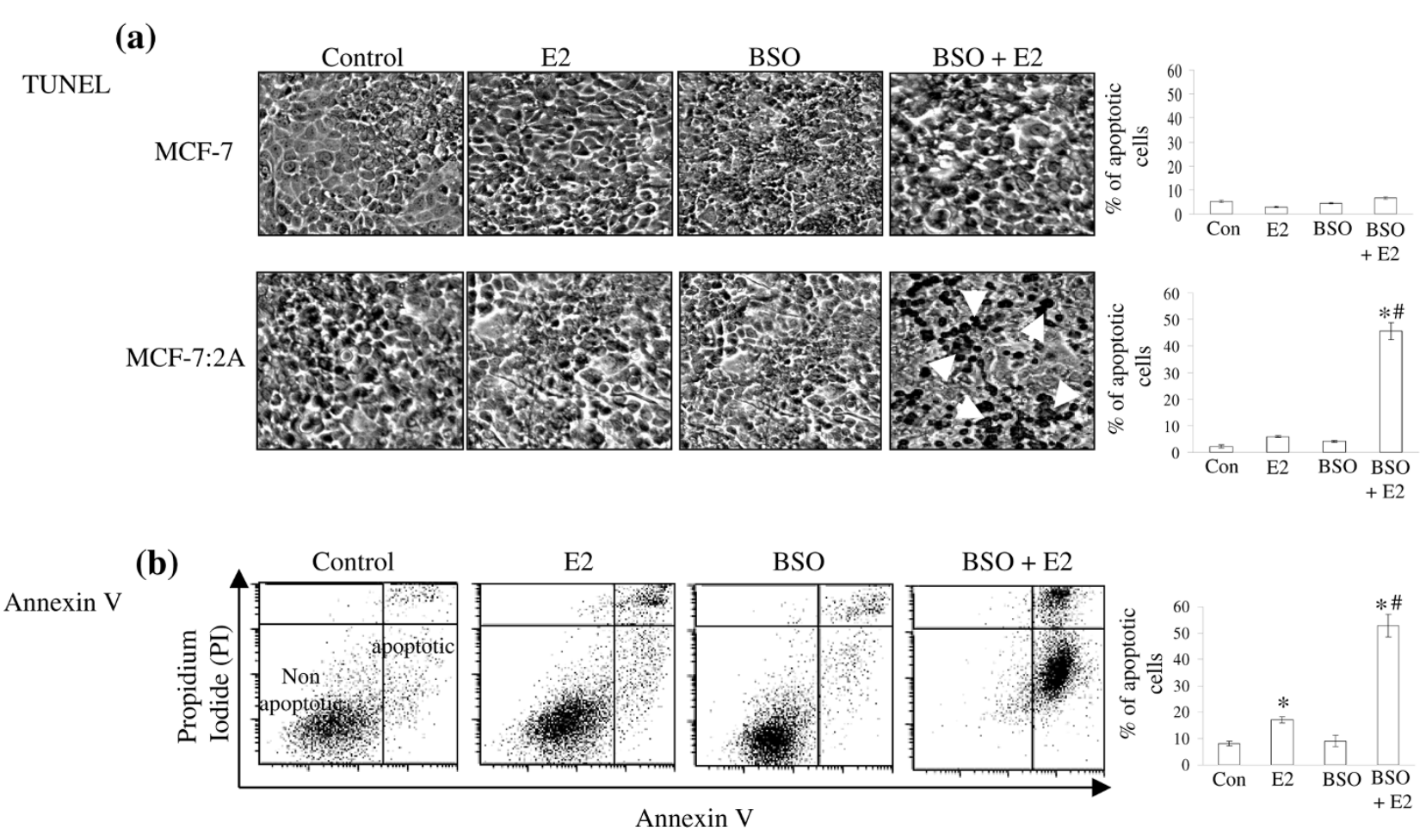

Buthionine sulfoximine (BSO) plus estradiol induce apoptosis in MCF-7:2A cells. (a) Terminal deoxynucleotidyl transferase-mediated dUTP nick endlabeling (TUNEL) staining for apoptosis in MCF-7:2A cells following BSO plus $17 \beta$-estradiol $\left(\mathrm{E}_{2}\right)$ treatment for $96 \mathrm{~h}$ were performed as described in Materials and methods. Slides were photographed through a brightfield microscope under $100 \times$ magnification. TUNEL-positive cells were stained black (white arrows). Columns (right), mean percentage of apoptotic cells (annexin V-positive cells) from three independent experiments performed in triplicate; bars, \pm standard error of the mean (SEM). ${ }^{*}, p<0.001$ compared with control cells;,$p<0.001$ compared with estradiol-treated cells. (b) Annexin V staining for apoptosis. Cells were seeded in $100 \mathrm{~mm}$ plates at a density of $1 \times 10^{6}$ per plate and after $24 \mathrm{~h}$ were treated with ethanol vehicle (control), $1 \mathrm{nM} \mathrm{E}_{2}$, or BSO plus $\mathrm{E}_{2}$ for $72 \mathrm{~h}$ and then stained with fluorescein isothiocyanate (FITC)-annexin V and propidium iodide (PI) and analyzed by flow cytometry. PI was used as a cell viability marker. Representative cytograms are shown for each group. Quantitation of apoptosis (percentage of control) in the different treatment groups is shown on the right. bars, \pm SEM. * $p<0.05$ compared with control cells; $\#, p<0.01$ compared with estradiol-treated cells.

pared to control siRNA (Figure 4b, top panel). Using annexin $V$ staining, we found that apoptosis was increased by $20 \%$ in Bcl-2 siRNA transfected cells compared with cells transfected with the control siRNA (Figure $4 \mathrm{~b}$, bottom panel), thus suggesting that suppression of antiapoptotic factors such as Bcl2 has the ability to partially sensitize hormone-independent MCF-7:2A cells to apoptosis.

We next examined mitochondrial membrane integrity using the Rh123 retention assay. Cells were treated with nothing (control), estradiol, BSO, or BSO plus estradiol for $48 \mathrm{~h}$. Figure $4 \mathrm{c}$ shows that BSO plus estradiol treatment reduced Rh123 fluorescence in MCF-7:2A cells by approximately 50\% compared to control, whereas, estradiol or BSO, as individual treatments, did not significantly alter Rh123 retention levels in these cells. BSO plus estradiol also enhanced cytochrome $c$ release in MCF-7:2A cells. Figure 4d shows that in the control cells, cytochrome $c$ was detected primarily in the mitochondria and was undetectable in the cytosol; however, in the presence of BSO plus estradiol (48 h), all of cytochrome $c$ was observed in the cytosol. BSO or estradiol, as individual treatments, did not significantly alter mitochondrial release of cytochrome $c$. The translocation of cytochrome $c$ from the mitochondria to the cytosol following BSO plus estradiol treatment coincided with cleavage of caspase 7 and PARP (Figure $4 \mathrm{e})$, which is a molecular signature of apoptosis. Cleavage of PARP and caspase 7 was blocked by the pan-caspase inhibitor z-VAD (data not shown).

\section{The apoptotic effect of BSO and estradiol in MCF-7:2A cells is regulated, in part, by JNK signaling}

Emerging evidence supports a role for JNK in stress-induced mitochondrial apoptotic pathways in a variety of cell systems [28]. Therefore, we examined the possible involvement of cJun/JNK pathway in BSO plus estradiol-induced apoptosis in MCF-7:2A cells. JNK activation was determined by western 
(a)

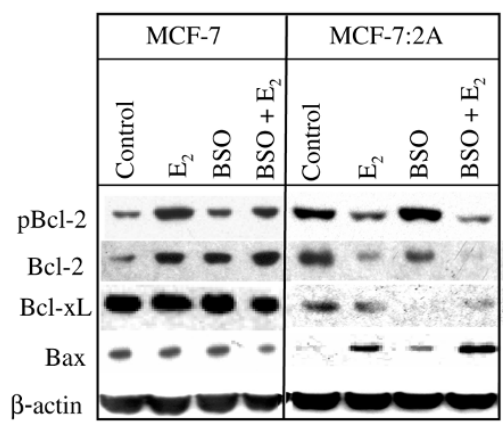

(b)

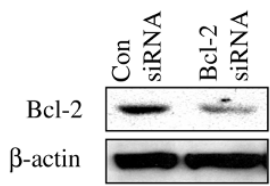

MCF-7:2A

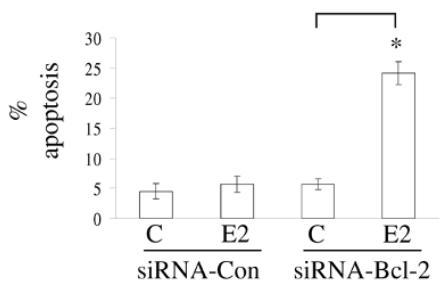

(c)

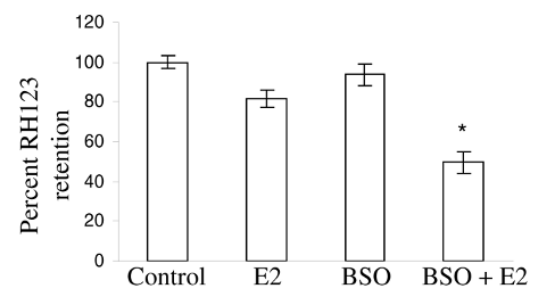

(d)

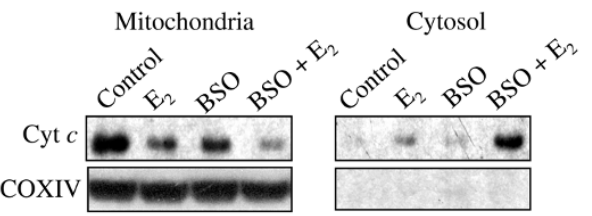

(e)

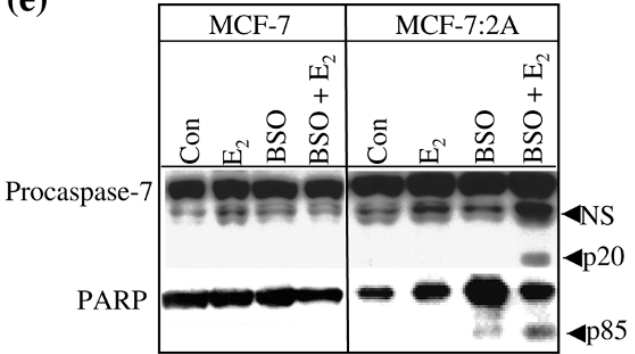

Effect of buthionine sulfoximine (BSO) and 17 $\beta$-estradiol $\left(\mathrm{E}_{2}\right)$ on Bcl-2 family protein expression and mitochondrial function in MCF-7 and MCF-7:2A cells. (a) Western blot analysis for $\mathrm{pBcl}-2, \mathrm{Bcl}-2, \mathrm{Bcl}-\mathrm{x}_{L}$, and Bax protein expression in parental MCF-7 cells and MCF-7:2A cells following $48 \mathrm{~h}$ of treatment with ethanol vehicle (Control), $1 \mathrm{nM} \mathrm{E}_{2}, 100 \mu \mathrm{M} \mathrm{BSO}$, or $\mathrm{E}_{2}+\mathrm{BSO}$. Equal loading was confirmed by reprobing with an antibody against $\beta$-actin. (b) Small interfering RNA (siRNA) knockdown of Bcl-2 partially sensitizes MCF-7:2A cells to $\mathrm{E}_{2}$-induced apoptosis. Cells were transfected with $100 \mathrm{nM}$ siRNA-Bcl-2 or siRNA-Con (control) and expression levels of Bcl-2 was determined by immunoblot analysis (top). Annexin V staining (bottom) showing the effects of siRNA-con and siRNA-Bcl-2 on apoptosis induced by estradiol treatment in MCF-7:2A cells. *, p < 0.001. (c) Loss of mitochondrial potential in MCF-7:2A cells was determined by rhodamine 123 (Rh123) retention assay. The percentage of cells retaining Rh123 in each treatment group was compared with untreated control. (d) Cytochrome $c$ release from the mitochondria to the cytosol after treatment with $\mathrm{E}_{2}$ alone or $\mathrm{BSO}$ and $\mathrm{E}_{2}$ for $48 \mathrm{~h}$ was determined as described in Materials and methods. Anti-Cox IV antibody was used as a control to demonstrate that mitochondrial protein fractionation was successfully achieved. (e) Cleavage of caspase 7 and poly(ADP-ribose) polymerase (PARP) (72 h) was assessed by western blot using specific antibodies. The upper band of caspase 7 represents the full-length protein and the lower band ( $p 20$, arrow) represents the cleaved activated product; NS, nonspecific. Full length PARP is approximately $116 \mathrm{kDa}$; cleaved (active) PARP is $85 \mathrm{kDa}$ (arrow). The results are representative of three independent experiments.

blot analysis after 48-h treatment of cells with BSO plus estradiol. A profound induction of the p54 and p46 isoforms of phosphorylated JNK as well as a significant increase in phospho-c-Jun and c-Jun were observed in MCF-7:2A cells treated with BSO plus estradiol compared to BSO alone or control (Figure 5a). Interestingly, treatment with estradiol alone also significantly increased phosphorylated JNK in MCF-7:2A cells. We also found that pretreatment of MCF-7:2A cells with the JNK inhibitor, SP600125 $(20 \mu \mathrm{M})$ markedly reduced the apoptotic effect of BSO plus estradiol in these cells (Figure $5 \mathrm{~b}$ ). Overall, these results suggest a possible involvement of the cJun/JNK signaling pathway in BSO plus estradiol-induced apoptosis in MCF-7:2A cells.

\section{BSO inhibits the growth of MCF-7:2A cells in vivo}

To determine whether the effect of BSO plus estradiol was relevant in vivo, we used a xenograft model in which MCF-7:2A cells were injected into CrTac:NCr-Foxn1 nu athymic mice $(n=$ 20). At 20 days post injection, tumors grew to a mean crosssectional area of $0.30 \mathrm{~cm}^{2}$ and mice were randomized to four groups; placebo (saline), estradiol, BSO, or the combination of BSO plus estradiol, as described in materials and methods. After 7 days of treatment, tumor growth was reduced by $25 \%$ in mice treated with estradiol alone whereas in the BSO and BSO plus estradiol group tumor growth was reduced by $40 \%$ and $60 \%$, respectively, compared to the placebo group which showed a $7 \%$ increase in growth (Figure 6a). Interestingly, we 
Figure 5

(a)

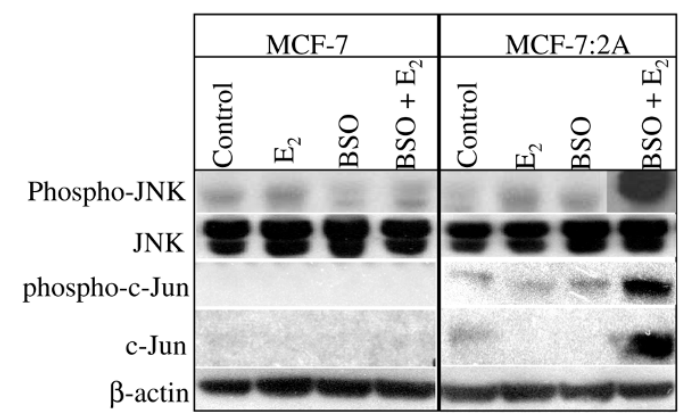

(b)

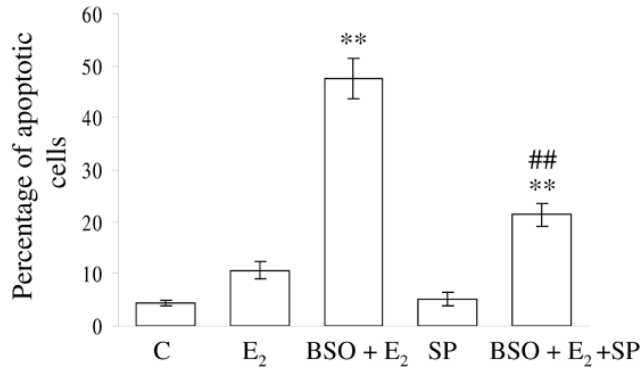

Activation of c-Jun N-terminal kinase (JNK) signaling pathway in MCF$7: 2 \mathrm{~A}$ cells in response to buthionine sulfoximine (BSO) and $17 \beta$-estradiol $\left(E_{2}\right)$ treatment. (a) MCF-7 and MCF-7:2A cells were treated with ethanol vehicle (control), $1 \mathrm{nM} \mathrm{E}_{2}$ or $100 \mu \mathrm{M} \mathrm{BSO}$ plus $\mathrm{E}_{2}$ for $48 \mathrm{~h}$ and protein levels of phosphorylated JNK, JNK, phosphorylated c-Jun, and $c$-Jun were analyzed by western blotting. $\beta$-Actin was used as a control. (b) Inhibition of JNK activation by SP600125 (SP) partially reverses the apoptotic effect of BSO and estradiol in MCF-7:2A cells. Cells were pretreated with $20 \mu \mathrm{M}$ SP600125 or vehicle for $24 \mathrm{~h}$, then further incubated for $48 \mathrm{~h}$ with $1 \mathrm{nM} \mathrm{E}_{2}, \mathrm{E}_{2}+100 \mu \mathrm{M}$ BSO, $20 \mu \mathrm{M} \mathrm{SP}$, or $\mathrm{E}_{2}+$ $\mathrm{BSO}+\mathrm{SP}$ and apoptosis was determined by annexin V-propidium iodide (PI) staining as described in Materials and methods. Columns, mean percentage of apoptotic cells from three independent experiments performed in triplicate; bars, \pm standard error of the mean (SEM). ${ }^{* *}, p<0.001$ compared with control (C) cells; ${ }^{\# \#, ~} p<0.01$ compared with $\mathrm{E}_{2}$ plus BSO-treated cells.

found that BSO in vitro had a relatively small effect on growth, however, in vivo its effect was very pronounced, thus suggesting the possibility of altered glutathione metabolism in vivo. We performed histology on tumors taken from placebo, estradiol, BSO, or BSO plus estradiol groups at day 27. H\&E staining of the BSO plus estradiol-treated tumors revealed less tumor cells and more intercellular matrix, significantly less mitoses, chromatin clumping and dark staining which are associated with apoptosis, and enhanced abnormalities in shape and size, compared to tumors from placebo or BSO or estradiol-treated groups (Figure 6b). We also characterized the proliferative status of these cells by staining tumors for the expression of Ki67, a marker of cell proliferation. We observed a $32 \%$ decrease $(p<0.001)$ in the number of Ki67 stained tumors from the BSO plus estradiol-treated group and a $21 \%$ decrease in the BSO-treated group compared to the placebo group whereas estradiol treatment caused an $8 \%$ increase in Ki67 staining (Figure 6c). Immunohistochemistry of paraffinembedded tumor sections of mice treated with the combination of BSO and estradiol showed increased immunostaining for proteolytically cleaved PARP (marker for apoptosis) compared to control, estradiol, or BSO-treated groups (Figure 6d). Overall, these data show that BSO either alone or in combination with estradiol, reduces tumor growth by inhibiting proliferation and increasing apoptosis.

\section{Discussion}

In the current study, we investigated whether suppression of the antioxidant glutathione by BSO has the ability to sensitize antihormone resistant MCF-7:2A breast cancer cells to estradiol-induced apoptosis. Our results showed that glutathione levels and the enzymes involved in its synthesis, glutathione synthetase and glutathione peroxidase, were significantly elevated in MCF-7:2A cells compared to parental MCF-7 cells and that suppression of glutathione by BSO sensitized these cells to estrogen-induced apoptosis in vitro and in vivo. The BSO-mediated estradiol-induced apoptosis was associated with a marked decrease in the expression of antiapoptotic Bcl2 and $\mathrm{Bcl}-\mathrm{xL}$ proteins and a significant increase in proapoptotic Bax protein. It is worth noting that high-dose estrogen was generally considered the endocrine therapy of choice for postmenopausal women with breast cancer prior to the introduction of tamoxifen, however, due to undesirable side effects, the use of high-dose estrogen was largely abandoned [29]. Here, we show that the killing effect of estradiol in antihormone resistant cells can be achieved at physiological concentrations when it is combined with non-toxic concentrations of BSO. Our present findings are consistent with previous studies which have shown that the cytotoxicity of a number of chemotherapeutic drugs, including melphalan [30], doxorubicin [31], and bleomycin [32], are significantly enhanced when glutathione is depleted by BSO.

An important target of BSO plus estradiol-induced apoptosis appears to be $\mathrm{Bcl}-2$, whose protein expression was dramatically decreased in MCF-7:2A cells following glutathione depletion. Previous studies have shown that Bcl-2 functions as an antioxidant to block apoptosis and that Bcl-2 protein levels and glutathione intracellular concentration is coordinately regulated with a decrease in either favoring cell death [23,33]. It is believed that one mechanism by which $\mathrm{Bcl}-2$ may function as an antioxidant is through upregulation of glutathione, leading to rapid detoxification of reactive oxygen species and inhibition of free radical-mediated mitochondrial damage. Bcl-2 also has the ability to shift the entire cellular redox potential to a more reduced state, which is independent of its effect on glutathione levels [33]. It is worth noting that glutathione levels 
(a)

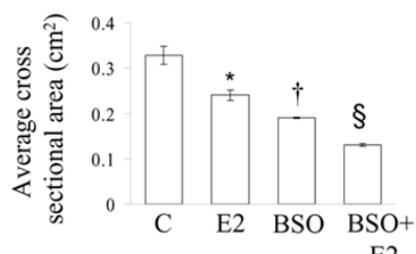

(b)

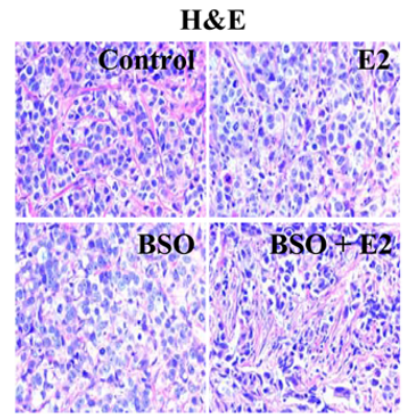

(c)

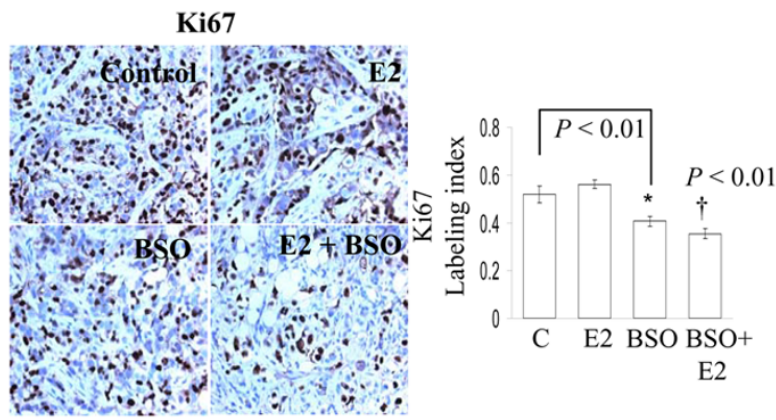

(d)

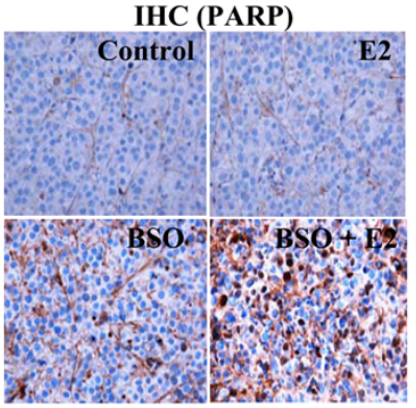

Buthionine sulfoximine (BSO) inhibits the growth of MCF-7:2A tumors in vivo. Athymic nude mice (4 to 5 weeks old, $n=20)$ were injected with MCF-7:2A breast cancer cells and after 20 days when tumors had reached a mean cross-sectional area of $0.3 \mathrm{~cm}^{2}$, animals were randomized into 4 groups and were treated with placebo (saline), $17 \beta$-estradiol $\left(E_{2}\right)$, BSO, or BSO plus $E_{2}$ for 7 days as described in Materials and methods. BSO (4 $\mathrm{mmol} / \mathrm{kg}$ weight) was diluted in saline and was injected intraperitoneally daily. (a) Tumor size was measured everyday and cross-sectional area was calculated by multiplying the length ( $/$ by the width $(w)$ by $\pi$ and dividing the product by $4(/ w \pi / 4)$. Data is shown as mean \pm standard error of the mean (SEM). *,$p<0.05$, control group compared with the $E_{2}$ group;,$+ p<0.002$ control group compared with BSO group; $\S p<0.001$ control group compared with BSO + E2 group. (b) Microscopy of hematoxylin and eosin (H\&E)-stained histological sections of MCF-7:2A tumors treated with placebo, $\mathrm{E}_{2}$, BSO, or BSO plus $\mathrm{E}_{2}$. (c) Immunohistochemical analysis of the proliferation marker Ki-67 in MCF-7:2A tumors treated with placebo, $E_{2}, B S O$, or $B S O$ plus $E_{2}$. (d) Paraffin-embedded tumor sections of mice treated with $E_{2}, B S O$, or $B S O$ plus $E_{2}$ were immunostained for proteolytically cleaved poly(ADP-ribose) polymerase (PARP), which exists only when cells undergo apoptosis. Three to four tumors per treatment group were analyzed.

and $\mathrm{Bcl}-2$ protein expression were significantly elevated in MCF-7:2A cells compared to parental MCF-7 cells. In phase I trials $[34,35]$, the concentration of BSO in blood has been shown to reach 0.5 to $1 \mathrm{mM}$, whereas, in mice $[36,37]$ the concentration has been estimated to be 5 to $6 \mathrm{mM}$ following an in vivo treatment of $4 \mathrm{mmol} / \mathrm{kg}$. In our study, we showed that $100 \mu \mathrm{M}$ BSO decreased glutathione concentrations by approximately $60 \%$ after $24 \mathrm{~h}$ and that BSO enhanced the apoptotic effect of estradiol in MCF-7:2A breast cancer cells as early as $48 \mathrm{~h}$ after treatment. Interestingly, treatment with BSO alone did not cause apoptosis in MCF-7:2A cells, indicating that glutathione depletion alone may not trigger apoptosis in these cells. This finding is consistent with previous studies by Mirkovic et al. [38] which showed that inhibition of glutathione by BSO did not increase susceptibility of mouse lymphoma cells to radiation-induced apoptosis even under conditions where glutathione levels were lowered by $50 \%$. Other groups have made similar observations using BSO [39]. One possible explanation for this apparent contradiction might be the fact that BSO does not lower glutathione levels in mito- chondria as effectively as it does in the cytoplasm [40]. Mitochondrial glutathione concentrations are regulated and have been implicated in apoptotic cell death [41], hence, it would be of interest to evaluate relative glutathione concentrations in the mitochondrial matrix of MCF-7:2A cells following treatment with BSO either alone or in combination with estradiol. Another possibility could be that cellular thiols other than glutathione may play important roles in regulating apoptosis [39]. The flavoprotein thioredoxin has been shown to be upregulated in several human tumors and is implicated in both cancer cell growth and apoptotic resistance [42]. However, it is not known whether $\mathrm{Bcl}-2$ or other apoptotic regulators can influence the levels of thioredoxin or whether such modulation may contribute to resistance in human tumor cells.

Apart from Bcl-2, we also found that proapoptotic Bax protein was markedly increased in MCF-7:2A cells by the combination of BSO plus estradiol and this induction coincided with a loss of mitochondrial membrane integrity and cytochrome $c$ release. Bax is normally found as a monomer in the cytosol of 
non-apoptotic cells and it oligomerizes and translocates to the outer mitochondrial membrane in response to apoptotic stimuli and induces mitochondrial membrane permeabilization and cytochrome $c$ release [19]. In MCF-7:2A cells, Bax protein was induced as early as $24 \mathrm{~h}$ after BSO plus estradiol treatment (Figure 4) and suppression of Bax expression using siRNA was able to partially reverse the apoptotic effect of the combination treatment (data not shown). The induction of Bax coincided with cytochrome $c$ release from the mitochondria into the cytosol, which was followed by activation of caspase 7 , and PARP cleavage. It is worth noting that pretreatment of cells with the universal caspase inhibitor z-VAD almost completely blocked the apoptotic effect of BSO plus estradiol. It is also worth noting that antiapoptotic $\mathrm{Bcl}-2$ and $\mathrm{Bcl}-\mathrm{xL}$ proteins were also markedly decreased in MCF-7:2A cells following the combination treatment of BSO plus estradiol (Figure 4) and overexpression of $\mathrm{Bcl}-\mathrm{xL}$ partially blocked the apoptotic effect of BSO plus estradiol (data not shown). This finding is important because there is evidence that suggests that the ratio rather than the amount of antiapoptotic vs proapoptotic proteins determines whether apoptosis will proceed [43]. Thus, it is reasonable to suggest that the apoptotic effect of BSO plus estradiol is mediated, in part, by the mitochondrial pathway through their ability to alter the ratio between proapoptotic and antiapoptotic proteins in target cells.

In addition to the mitochondrial pathway, BSO plus estradiol appears to induce apoptosis, in part, through activation of the JNK signaling pathway. JNKs are a group of mitogen-activated protein kinases (MAPKs) that bind the $\mathrm{N}$-terminal activation domain of the transcription factor c-Jun and phosphorylate cJun on amino acid residues Ser63 and Ser73 [44]. JNKs are stimulated by multiple factors including cytokines, DNA-damaging agents, and environmental stresses and are important in controlling programmed cell death or apoptosis. The inhibition of JNKs has been shown to enhance chemotherapy-induced inhibition of tumor cell growth, suggesting that JNKs may provide a molecular target for the treatment of cancer [44]. We found that JNK activation (as measured by the increased levels of phospho-JNK1/2 and the JNK substrate phospho-c-Jun) correlated well with BSO plus estradiol-induced apoptosis in MCF-7:2A cells and pharmacologic disruption of this pathway using the JNK inhibitor SP600125 significantly attenuated this effect. Previously, Chen and coworkers [45] reported that BSO enhanced the apoptotic effect of arsenic $\left(\mathrm{As}_{2} \mathrm{O}_{3}\right)$ in leukemia and lymphoma cells through activation of JNK and upregulation of death receptor (DR) 5 and that inhibition of JNK by SP600125 decreased DR5 upregulation and apoptotic induction in U937 leukemia cells treated with arsenic plus BSO. While the exact mechanism by which JNK promotes apoptosis is not currently known, the phosphorylation of transcription factors such as c-Jun and p53, as well as pro- and antiapoptotic Bcl-2 family members [46] has been suggested to be of importance. It is worth noting that treatment with BSO plus estradiol markedly increased phosphorylated c-Jun in
MCF-7:2A cells and decreased phosphorylated Bcl-2 in these cells. These findings thus suggest that BSO plus estradiol might mediate their apoptotic effect, in part, through activation of JNK.

\section{Conclusion}

We have demonstrated that glutathione depletion by BSO sensitizes hormone-resistant MCF-7:2A human breast cancer cells to estradiol-induced apoptosis in vitro and in vivo. This finding has important clinical implications; particularly for the use of estrogen deprivation as long-term therapy, and it suggest that, if and when resistance develops, a strategy of treatment with estrogen combined with BSO may be effective in sensitizing resistant cells to apoptosis. It is worth noting that recently, Lonning and coworkers [9] reported a 33\% complete response (that is, stable disease) with high dose diethylstilbestrol (DES) in postmenopausal patients with advanced breast cancer who were heavily pretreated with endocrine agents. However, $67 \%$ of the patients showed partial or no response [9] so the key to future clinical progress in the treatment of antihormone resistant breast cancer is to improve current treatment strategies. We are currently evaluating the optimal dose of daily estradiol therapy to reverse antihormonal resistance [4] but the goal is to enhance the estradiol-induced apoptotic response. The present findings suggest that BSO is indeed capable of enhancing the apoptotic effect of estradiol in antihormone resistant breast cancer cells. It is worth noting that a phase I study of BSO administered with the anticancer drug melphalan showed that continuous-infusion of BSO was relatively nontoxic and resulted in depletion of tumor glutathione $[35,47]$. Thus it is possible that future clinical studies of BSO infusions combined with low dose estrogen hold the promise of improving disease control for patients with antihormone resistant ER-positive metastatic breast cancer.

\section{Competing interests}

The authors declare that they have no competing interests. The views and opinions of the author(s) do not reflect those of the US Army or the Department of Defense.

\section{Authors' contributions}

JSLW designed and coordinated the studies, analyzed the data and interpreted the results, generated the figures, and wrote and revised the manuscript. HK performed the cell proliferation assays and the western blots. $\mathrm{CW}$ performed the glutathione assay. RP and JP performed the animal experiments. AJK performed the immunohistochemistry. VCJ is the Principal Investigator (PI) of the laboratory in which all experiments were conducted and is the recipient of the grant that partially funded the project. VCJ was instrumental in revising the manuscript. All authors read, assisted in revision and approved the final manuscript. 


\section{Additional files}

The following Additional files are available online:

\section{Additional file 1}

Powerpoint file showing the growth inhibitory effect of buthionine sulfoximine (BSO) and $17 \beta$-estradiol $\left(E_{2}\right)$ in MCF-7:2A cells is reversed by the antiestrogen 4hydroxytamoxifen (4-OHT). MCF-7:2A cells $(30,000 /$ well) were seeded in 24-well plates and after $24 \mathrm{~h}$ were treated with $<0.1 \%$ ethanol vehicle (control), $1 \mathrm{nM} \mathrm{E}_{2}$, $100 \mu \mathrm{M}$ BSO, $100 \mu \mathrm{M}$ BSO plus $1 \mathrm{nM} \mathrm{E}_{2}, 1 \mu \mathrm{M} 4-\mathrm{OHT}$, $4-\mathrm{OHT}+\mathrm{E}_{2}, 4-\mathrm{OHT}+\mathrm{BSO}, 4-\mathrm{OHT}+\mathrm{E}_{2}+\mathrm{BSO}$ for 7 days. At the indicated time points, cells were harvested and total DNA ( $\mu \mathrm{g} / \mathrm{well}$ ) was quantitated as described in Materials and methods. The data represent the mean of three independent experiments; bars, \pm standard error of the mean (SEM). * $p<0.01$ compared with control cells; $\#, p<0.01$ compared to $E_{2}$-treated cells.

See http://www.biomedcentral.com/content/ supplementary/bcr2208-S1.ppt

\section{Acknowledgements}

This work was supported by the Department of Defense Breast Program under award number BC050277 Center of Excellence (VCJ); Fox Chase Cancer Center Core Grant NIH P30 CA006927 (VCJ); Weg Fund of Fox Chase Cancer Center (VCJ); a gift from Genuardi's (VCJ), the American Cancer Society Grant IRG-92-027-14 (JSLW); the Hollenbach Family Fund (JSLW), and the NIH Career Development Grant K01CA120051-01A2 (JSLW). Histology and immunohistochemistry were performed by the Histopathology Core Facility at Fox Chase Cancer Center.

\section{References}

1. Herold Cl, Blackwell KL: Aromatase inhibitors for breast cancer: proven efficacy across the spectrum of disease. Clin Breast Cancer 2008, 8:50-64.

2. Santen RJ, Song RX, Masamura S, Yue W, Fan P, Sogon T, Hayashi $\mathrm{S}$, Nakachi K, Eguchi H: Adaptation to estradiol deprivation causes up-regulation of growth factor pathways and hypersensitivity to estradiol in breast cancer cells. Adv Exp Med Biol 2008, 630:19-34.

3. Jordan VC, O'Malley BW: Selective estrogen-receptor modulators and antihormonal resistance in breast cancer. J Clin Oncol 2007, 25:5815-5824.

4. Jordan VC: The 38th David A. Karnofsky lecture: the paradoxical actions of estrogen in breast cancer - survival or death? $J$ Clin Oncol 2008, 26:3073-3082.

5. Santen RJ, Allred DC: The estrogen paradox. Nat Clin Pract Endocrinol Metab 2007, 3:496-497.

6. Song RX, Mor G, Naftolin F, McPherson RA, Song J, Zhang Z, Yue $W$, Wang J, Santen RJ: Effect of long-term estrogen deprivation on apoptotic responses of breast cancer cells to 17 beta-estradiol. J Nat/ Cancer Inst 2001, 93:1714-1723.

7. Pink JJ, Jiang SY, Fritsch M, Jordan VC: An estrogen-independent MCF-7 breast cancer cell line which contains a novel 80kilodalton estrogen receptor-related protein. Cancer Res 1995, 55:2583-2590.

8. Lewis JS, Meeke K, Osipo C, Ross EA, Kidawi N, Li T, Bell E, Chandel NS, Jordan VC: Intrinsic mechanism of estradiol-induced apoptosis in breast cancer cells resistant to estrogen deprivation. J Natl Cancer Inst 2005, 97:1746-1759.
9. Lonning PE, Taylor PD, Anker G, Iddon J, Wie L, Jorgensen LM, Mella O, Howell A: High-dose estrogen treatment in postmenopausal breast cancer patients heavily exposed to endocrine therapy. Breast Cancer Res Treat 2001, 67:111-116.

10. Anderson CP, Tsai JM, Meek WE, Liu RM, Tang Y, Forman HJ, Reynolds CP: Depletion of glutathione by buthionine sulfoxine is cytotoxic for human neuroblastoma cell lines via apoptosis. Exp Cell Res 1999, 246:183-192.

11. Schroder CP, Godwin AK, O'Dwyer PJ, Tew KD, Hamilton TC, Ozols RF: Glutathione and drug resistance. Cancer Invest 1996, 14:158-168.

12. Anderson ME: Glutathione: an overview of biosynthesis and modulation. Chem Biol Interact 1998, 111-112:1-14.

13. Townsend DM, Tew KD, Tapiero $\mathrm{H}$ : The importance of glutathione in human disease. Biomed Pharmacother 2003, 57:145-155.

14. Hammond CL, Lee TK, Ballatori N: Novel roles for glutathione in gene expression, cell death, and membrane transport of organic solutes. J Hepato/ 2001, 34:946-954.

15. Schnelldorfer T, Gansauge S, Gansauge F, Schlosser S, Beger HG, Nussler AK: Glutathione depletion causes cell growth inhibition and enhanced apoptosis in pancreatic cancer cells. Cancer 2000, 89:1440-1447.

16. Rudin CM, Yang Z, Schumaker LM, VanderWeele DJ, Newkirk $K$ Egorin MJ, Zuhowski EG, Cullen KJ: Inhibition of glutathione synthesis reverses $\mathrm{Bcl}-2$-mediated cisplatin resistance. Cancer Res 2003, 63:312-318.

17. Fulda S, Debatin KM: Targeting inhibitor of apoptosis proteins (IAPs) for diagnosis and treatment of human diseases. Recent Patents Anticancer Drug Discov 2006, 1:81-89.

18. Fulda S, Debatin KM: Extrinsic versus intrinsic apoptosis pathways in anticancer chemotherapy. Oncogene 2006, 25:4798-4811.

19. Youle RJ, Strasser A: The BCL-2 protein family: opposing activities that mediate cell death. Nat Rev Mol Cell Biol 2008, 9:47-59.

20. Peter ME, Krammer PH: The CD95(APO-1/Fas) DISC and beyond. Cell Death Differ 2003, 10:26-35.

21. Newmeyer DD, Ferguson-Miller S: Mitochondria: releasing power for life and unleashing the machineries of death. Cell 2003, 112:481-490.

22. Meredith MJ, Cusick CL, Soltaninassab S, Sekhar KS, Lu S, Freeman ML: Expression of $\mathrm{Bcl}-2$ increases intracellular glutathione by inhibiting methionine-dependent GSH efflux. Biochem Biophys Res Commun 1998, 248:458-463.

23. Voehringer DW: BCL-2 and glutathione: alterations in cellular redox state that regulate apoptosis sensitivity. Free Radic Biol Med 1999, 27:945-950.

24. Swaby RF, Jordan VC: Low-dose estrogen therapy to reverse acquired antihormonal resistance in the treatment of breast cancer. Clin Breast Cancer 2008, 8:124-133.

25. Labarca C, Paigen K: A simple, rapid, and sensitive DNA assay procedure. Anal Biochem 1980, 102:344-352.

26. O'Regan RM, Cisneros A, England GM, MacGregor Jl, Muenzner HD, Assikis VJ, Bilimoria MM, Piette M, Dragan YP, Pitot HC, Chatterton R, Jordan VC: Effects of the antiestrogens tamoxifen, toremifene, and $\mathrm{ICl} \mathbf{1 8 2 , 7 8 0}$ on endometrial cancer growth. $J$ Natl Cancer Inst 1998, 90:1552-1558.

27. Kane DJ, Sarafian TA, Anton R, Hahn H, Gralla EB, Valentine JS, Ord T, Bredesen DE: Bcl-2 inhibition of neural death: decreased generation of reactive oxygen species. Science 1993, 262:1274-1277.

28. Bossy-Wetzel E, Bakiri L, Yaniv M: Induction of apoptosis by the transcription factor c-Jun. EMBO J 1997, 16:1695-1709.

29. Haddow AW, Paterson E: Influence of synthetic oestrogens upon advanced malignant disease. BMJ 1944, 2:393-398.

30. Kramer RA, Greene K, Ahmad S, Vistica DT: Chemosensitization of L-phenylalanine mustard by the thiol-modulating agent buthionine sulfoximine. Cancer Res 1987, 47:1593-1597.

31. Dusre L, Mimnaugh EG, Myers CE, Sinha BK: Potentiation of doxorubicin cytotoxicity by buthionine sulfoximine in multidrug-resistant human breast tumor cells. Cancer Res 1989, 49:511-515.

32. Russo A, DeGraff W, Friedman N, Mitchell JB: Selective modulation of glutathione levels in human normal versus tumor cells and subsequent differential response to chemotherapy drugs. Cancer Res 1986, 46:2845-2848. 
33. Ellerby LM, Ellerby HM, Park SM, Holleran AL, Murphy AN, Fiskum G, Kane DJ, Testa MP, Kayalar C, Bredesen DE: Shift of the cellular oxidation-reduction potential in neural cells expressing Bcl-2. J Neurochem 1996, 67:1259-1267.

34. O'Dwyer PJ, Hamilton TC, LaCreta FP, Gallo JM, Kilpatrick D, Halbherr T, Brennan J, Bookman MA, Hoffman J, Young RC, Comis RL, Ozols RF: Phase I trial of buthionine sulfoximine in combination with melphalan in patients with cancer. J Clin Oncol 1996, 14:249-256.

35. Bailey HH, Ripple G, Tutsch KD, Arzoomanian RZ, Alberti D, Feierabend C, Mahvi D, Schink J, Pomplun M, Mulcahy RT, Wilding G: Phase I study of continuous-infusion L-S, R-buthionine sulfoximine with intravenous melphalan. J Natl Cancer Inst 1997, 89:1789-1796.

36. Kang YJ, Uthus EO: Suppression of plasma estradiol and progesterone concentrations by buthionine sulfoximine in female rats. Biochem Pharmacol 1996, 51:567-570.

37. Morrison JP, Coleman MC, Aunan ES, Walsh SA, Spitz DR, Kregel $\mathrm{KC}$ : Aging reduces responsiveness to BSO- and heat stressinduced perturbations of glutathione and antioxidant enzymes. Am J Physiol Regul Integr Comp Physiol 2005, 289:R1035-1041.

38. Mirkovic N, Voehringer DW, Story MD, McConkey DJ, McDonnell TJ, Meyn RE: Resistance to radiation-induced apoptosis in Bcl2-expressing cells is reversed by depleting cellular thiols. Oncogene 1997, 15:1461-1470.

39. Sato N, Iwata S, Nakamura K, Hori T, Mori K, Yodoi J: Thiol-mediated redox regulation of apoptosis. Possible roles of cellular thiols other than glutathione in $\mathrm{T}$ cell apoptosis. J Immunol 1995, 154:3194-3203.

40. Griffith OW, Meister A: Origin and turnover of mitochondrial glutathione. Proc Natl Acad Sci USA 1985, 82:4668-4672.

41. Martensson J, Meister A: Mitochondrial damage in muscle occurs after marked depletion of glutathione and is prevented by giving glutathione monoester. Proc Natl Acad Sci USA 1989, 86:471-475.

42. Baker A, Payne CM, Briehl MM, Powis G: Thioredoxin, a gene found overexpressed in human cancer, inhibits apoptosis in vitro and in vivo. Cancer Res 1997, 57:5162-5167.

43. Jacobson MD, Raff MC: Programmed cell death and Bcl-2 protection in very low oxygen. Nature 1995, 374:814-816.

44. Vasilevskaya I, O'Dwyer PJ: Role of Jun and Jun kinase in resistance of cancer cells to therapy. Drug Resist Updat 2003, 6:147-156.

45. Chen $D$, Chan $R$, Waxman $S$, Jing $Y$ : Buthionine sulfoximine enhancement of arsenic trioxide-induced apoptosis in leukemia and lymphoma cells is mediated via activation of c-Jun $\mathrm{NH}_{2}$-terminal kinase and up-regulation of death receptors. Cancer Res 2006, 66:11416-11423.

46. Park J, Kim I, Oh YJ, Lee K, Han PL, Choi EJ: Activation of c-Jun $\mathrm{N}$-terminal kinase antagonizes an anti-apoptotic action of $\mathrm{Bcl}-$ 2. J Biol Chem 1997, 272:16725-16728.

47. Bailey HH, Mulcahy RT, Tutsch KD, Arzoomanian RZ, Alberti D, Tombes MB, Wilding G, Pomplun M, Spriggs DR: Phase I clinical trial of intravenous L-buthionine sulfoximine and melphalan: an attempt at modulation of glutathione. J Clin Oncol 1994, 12:194-205. 